\title{
Mixing Characteristics for the single and air-water two-phase flows in multichannel-based miniaturized fixed-bed devices
}

\author{
Somen Mondal ${ }^{1}$ and Subrata Majumder ${ }^{1}$ \\ ${ }^{1}$ Indian Institute of Technology Guwahati
}

July 15, 2021

\begin{abstract}
Investigation on the miniaturized multichannel-based fixed-bed devices to enhance the heat and mass transfer performance is the key focus in the present study. Residence time distribution (RTD) is one of the most critical parameters to characterize the device's flow distribution. In the current context, the RTDs of a liquid tracer for the air-water two-phase concurrent flows across the multichannel-based miniaturized fixed-bed devices (consist of 11 number of same dimensional parallel channels) with the variable heights were measured by the conductivity measurements and represented by axial dispersion model (ADM). The stream-flow rates of the two phases varied within the range of $8.33 \times 10-8-3.83 \times 10-7 \mathrm{~m} 3 \mathrm{~s}-1$. The axial dispersion coefficients and the specific energy dissipation values were analyzed. The impacts of pressure loss and the geometry on the hydrodynamic characteristics and mixing properties were well expressed. Based on the experimental data, new correlations were proposed.
\end{abstract}

\section{Hosted file}

Manuscript.docx available at https://authorea.com/users/345354/articles/530582-mixingcharacteristics-for-the-single-and-air-water-two-phase-flows-in-multichannel-basedminiaturized-fixed-bed-devices

\section{Hosted file}

Figures.docx available at https://authorea.com/users/345354/articles/530582-mixingcharacteristics-for-the-single-and-air-water-two-phase-flows-in-multichannel-basedminiaturized-fixed-bed-devices

\section{Hosted file}

Tables.docx available at https://authorea.com/users/345354/articles/530582-mixingcharacteristics-for-the-single-and-air-water-two-phase-flows-in-multichannel-basedminiaturized-fixed-bed-devices 